\title{
A Comparative Analysis of Hotel Staff Opinions on the Positive Effects of Tourists by Demographic Variables: The Cases of Antalya and Eskişehir Provinces
}

\author{
Oktay Emir ${ }^{A}$ \\ Received: November 2017 | Accepted: December 2017 \\ DOI: 10.5937/turizam21-16719
}

\begin{abstract}
The factor of employee quality is crucial in tourism because it is a sector focused primarily on serving individuals. The fact that hotel establishments are expected to provide $24 / 7$ uninterrupted service makes it more important that the customers and employees are in constant communication and the employees are qualified. Tourists always wish to have happy moments throughout their travel and hope to return home with cherishable memories of the trip. For this reason, hotel staff opinions about the positive effects of tourists will contribute both to the tourism sector and to serving tourists better. According to the results of the study, while no significant relationship was found between the demographic characteristics of the employees and the perceived positive effects of tourists staying in Antalya hotels, certain differences emerged concerning some staff demographics in Eskişehir.
\end{abstract}

Keywords: demographic, staffopinions, tourist, Antalya, Eskişehir

\section{Introduction}

With the Sumerians inventing the wheel, travel has become more convenient despite being still limited. Over the course of time, the technological advances have led to the increased diversification in the alternative means of transport we all enjoy today and the modern popularization of traveling. In the past, people who moved to other places for reasons such as marriage, security, nutrition, etc. have now started to go on journeys for other purposes such as sightseeing, relaxing, and having fun. Tourism has become an important economic and social phenomenon in the modern world. The person who is the focus of the academic field of tourism is called "tourist" in the tourism literature. In paragraphs 1 and 2 of Article 13 of the "Universal Declaration of Human Rights" adopted by resolution 217 (111) of the General Assembly of the United Nations of 10/12/1948, the decisions regarding freedom to travel are stated as follows (Resmi Gazete, 1949):

A Anadolu University, Faculty of Business Administration, Department of Hospitality Management Yunusemre Campus 26470, Eskisehir, Turkey, oktayemir@anadolu.edu.tr 
1. "Everyone has the right to freely navigate and reside within the territory of any State,

2. Everyone has the right to leave any country, including his own, and to return to his country".

This decision of the General Assembly of the United Nations undoubtedly contributed to the development of tourism. In addition, the international acceptance of this declaration has brought some obligations for nations on freedom of travel. Of course, it may not always be possible for individuals to travel whereever they want whenever they want, albeit it is significant that the individual's freedom of travel is given legal assurance. Aybay (1979: 81) states that the Universal Declaration of Human Rights omits an individual's right to "enter another country." This can be justified by many reasons, such as aiming to prevent travel for permanent settlement, ensure security, or controlling excessive traffic intensity. Undoubtedly, every legal arrangement to be made in the travel field will contribute to the development of the tourism, provided that the purchasing power of the individuals increases. Today, the economic magnitude that the tourism sector has reached is remarkable. Nations that send tourists and welcome tourists compete in the race to get a slice from this cake. According to World Tourism Organization (2016) statistics, 1.235 billion people have traveled around the world. Paralleling the rise in individual income, free time, marketing, technological and cultural developments, the number of travelers will keep rising in the coming years. The key here is passing the touristic attractions on to future generations by preventing their deterioration while maintaining this growth. Advanced societies do not see tourists only as a source of revenue, but they see them as a part of their social life and an element of cultural change. However, in the underdeveloped societies, tourists are mainly seen as individuals whose primary function is contributing to the host economy. In other words, we can say that the concept of "tourist" is perceived differently in developed and less developed societies. The huge influx of tourists to the countries which are popular tourist destinations like Spain and Italy has caused local people's hostile reactions towards them. Perhaps in the near future specific visitor quotas will be set for popular tourist destinations, thus mitigating conflicts between tourists and the local people. So much so that, in the near future certification training may be needed to have "conscious tourists."

The main objective of this study is to determine the opinions of hotel staff regarding the positive effects of tourists. The review of the relevant literature failed to identify any similar research to date which is directly dealing with this subject. In general, the related studies include topics such as "tourist image of the country," "tourist typologies," "tourist behaviors," "tourist perception of the local people" and "tourist perception of the service." This section will present some national and international research findings in the field of tourism and will provide personal comments on the topic. While the previous research cited here may not be closely related to the present study, it is still hoped to help deepen the understanding of the subject. Ateşoğlu and Türker's (2013) study showed that especially in touristic areas the employees are unqualified, which negatively affects the perceptions of tourists about Turkey. In addition, the research conducted by Yilmazer and Bahadır (2011) found out that a significant number of the front office staff working in the hospitality establishments are not properly informed about the code of professional ethics. A study of the front office, housekeeping, and food-beverage departments by Keung (200o) to explain the ethical issues of tourist perceptions also revealed that the front office staff have a higher level of positive tourist perceptions. In addition, Kattara et al. (2015) found that hotel employee behavior is very effective on overall customer satisfaction. There is no doubt that the problem of unqualified staff is the cause of other problems. A qualified employee is a person who fulfills the assigned duties professionally and acts as the 
communication bridge between the business and the tourists. Obviously, unqualified hotel staff cannot make the expected positive contribution to tourism and tourists, resulting in negative tourist perceptions. Türker and Türker's (2014) findings indicate that workers employed in the tourism industry with direct financial gains from tourism perceive the impacts of tourism more positively than other occupational groups residing in the region and are more likely to support tourism. Obviously, such a positive employee attitude towards tourism influences the tourist perceptions favorably, but the tourism activity itself can only be realized with the actual participation of tourists. Tourists are the spenders, and the employees are aware of this. Tourists consume social, cultural and physical values in exchange for their expenditures. Establishing a balance between spending and consumption will positively affect tourism sustainability. Toprak (2015) lists "protecting the cultural essence of the community that welcomes tourists and its tourism employees" among the conditions for long-term sustainability. Local culture is a charm for tourists, which highlights the importance of preserving cultural values. The results obtained by Tan et al. (2014) demonstrate that creative tourists are the co-creators of their own experiences. Nowadays, tourists are traveling to have first-hand authentic experiences of the traditional local life and gain different understandings. Therefore, tourism destinations that can successfully maintain their local characteristics are always a source of tremendous interest. Matzler et al. (2016) argue that tourism destinations increasingly use brand personality strategies to attract tourists. Rahman (2012), on the other hand, emphasizes that most tourists also carefully consider the brand image and previous customer satisfaction of the destination in making a destination selection. Özel's (2010) study shows that the socio-economic and travel behavior characteristics of various tourist types differ from each other. In addition, Kongprasert and Virutamasen (2015) assert that the simple delivery of good product design and good quality in the tourism market is insufficent for survival in such a competitive market, and that by utilizing an emotional design approach, tourists' behavioral patterns and preferences must be examined so as to ensure that the products and services to be delivered will match their expectations. Therefore, being aware of the various types of tourists is helpful for hotel staff. The consumptions, travel styles or anticipations of each tourist type are different from each other, and the hotel staff who are aware of these differences will meet tourists' expectations better. Varol (2015) found that business owners and employees are sensitive to the wishes and complaints of tourists and that they can put themselves in tourists' shoes. Such behaviors facilitate the prevention and resolution of problems between the business and tourists and positively affect the results. In the research they conducted, Çalışkan and Ünüsan (2011) determined that hotel staff' perception of corporate social responsibility decreases as their daily work time increases. Overtime is the main problem of hotel staff, and this negatively affects employee motivation. Naturally, it would be unfair to expect the hotel employee in such a situation to make an objective assessment of tourism and tourists. Also, Boğan and Sarışık (2016) report that individuals with a relative who is employed in the tourism industry show a stronger agreement that tourism has a socially positive effect. Egbali et al. (2011) draw attention to the fact that many people do not consider the surroundings outside their home as part of their environment and do not feel any responsibility to protect it, but improving tourism requires protection of the natural environment. They assert that ensuring tourist satisfaction through eco-friendly approaches will further enhance the benefits expected from tourism. 


\section{Methodology}

This descriptive study aims to determine whether there is a difference, depending on demographic status, in hotel workers' opinions about the positive effects of the tourists. The data collection tool used in the study is the survey method. The first part of the questionnaire is composed of 9 demographic questions and the second part comprises 5 Likert type questions asking for an evaluation of the positive attributes of tourists. The rating ranges from "I absolutely disagree" $=1$ to "I absolutely agree" $=5$. The second part of the questionnaire was created by examining previously conducted studies (Eralp, 1974; Burkart, Medlik, 1986; Ahmed, 1987; Toksay, 1989; Tsartas, 1992; Dogan, 2004; Roney, 2011). The content validity and clarity of the questionnaire was also checked and confirmed by experts. The reliability of the questionnaire was also analyzed and determined to be within the confidence levels. As positive effects of the tourists, the judgments "The tourist travels for cultural needs", "The tourist is a person who spends money", "The tourist wants to be psychologically satisfied", "The tourist travels for physical (rest, health, etc.) needs", "The tourist expects his/her demands to be met unquestioningly" were included in the questionnaire form.

The population of the study is composed of staff working at various officially-certified hotel enterprises in Antalya and Eskişehir provinces (in 2015). The sample size (calculated as 385 participants for each province) was determined by using Özdamar's (2001) non-finite population $(\mathrm{N}>10000)$ and the $\mathrm{n}=\sigma^{2} \mathrm{Z}_{\alpha}^{2} / \mathrm{H}^{2}$ formula proposed for quantitative surveys. However, in order to increase the reliability of the study and expecting that there could be some invalid returned surveys, it was decided that 900 people needed to be sampled. By using the simple random sampling method, a total of 874 questionnaires (391 in Antalya and 483 in Eskişehir) were accepted as valid. In the case of the normal distribution of the data, the t-test was used in the binary comparisons and the variance analysis was used in the comparison between the two cases with more than two groups. Tukey was used for the homogeneous variances, and Tamhane pos-hoc tests were used for the heterogeneous variances.

\section{Results}

Table 1 shows the distribution of the demographic characteristics for the province of Antalya, and the test results indicating whether the staff opinions regarding the positive effects of the tourists differ between the staff groups. As can be seen in Table 1, 57.3\% of the total sample are men and $4.2 .7 \%$ are women. Regarding the age groups, $3.8 \%$ are aged 20 and younger, $37.6 \%$ are $21-30,38.4 \%$ are $31-4.0,17.4 \%$ are $41-50$, and $2.8 \%$ are over 51 years old. The study sought answers for the following questions:

- Is there a statistically significant relationship between the perceived positive effects of tourists and the gender of staff?

- Is there a statistically significant relationship between the perceived positive effects of tourists and the age of staff?

- Is there a statistically significant relationship between the perceived positive effects of tourists and the marital status of staff?

- Is there a statistically significant relationship between the perceived positive effects of tourists and the education level of staff?

- Is there a statistically significant relationship between the perceived positive effects of tourists and the staff's year of experience in the tourism sector? 
- Is there a statistically significant relationship between the perceived positive effects of tourists and the staff's department of employment?

- Is there a statistically significant relationship between the perceived positive effects of tourists and the staff's length of work experience at the current hotel?

- Is there a statistically significant relationship between the perceived positive effects of tourists and the staff's prior formal tourism training?

- Is there a statistically significant relationship between the perceived positive effects of tourists and the staff's previous participation in tourism as tourists?

The questions above were tested by t-test and analysis of variance. Also, the questions were accepted as affirmative for those rejected at the $95 \%$ significance level. The tests revealed no statistically significant difference between the groups regarding their views on the positive effects of tourists at the $95 \%$ confidence level. As can be seen in Table 1 , all of their $\mathrm{p}=$ sig values are greater than 0.05 .

Table 1. Hotel staff opinions by their demographic status (Antalya)

\begin{tabular}{|c|c|c|c|}
\hline Gender & $\mathrm{n}$ & $\%$ & $P$ \\
\hline Male & 224 & 57.3 & \multirow{2}{*}{0.275} \\
\hline Female & 167 & 42.7 & \\
\hline Age Groups & $\mathrm{n}$ & $\%$ & $P$ \\
\hline 20 and under & 15 & 3.8 & \multirow{5}{*}{0.165} \\
\hline $21-30$ & 147 & 37.6 & \\
\hline $31-40$ & 150 & 38.4 & \\
\hline $41-50$ & 68 & 17.4 & \\
\hline $51+$ & 11 & 2.8 & \\
\hline Marital Status & $n$ & $\%$ & $p$ \\
\hline Married & 234 & 59.8 & \multirow{2}{*}{0,988} \\
\hline Single & 157 & 40.2 & \\
\hline Level of Education & $\mathrm{n}$ & $\%$ & $P$ \\
\hline Primary school & 75 & 19.2 & \multirow{5}{*}{0.654} \\
\hline High school & 155 & 39.6 & \\
\hline Associate & 59 & 15.1 & \\
\hline Undergraduate & 88 & 22.5 & \\
\hline Graduate & 14 & 3.6 & \\
\hline Experience in the Sector & $\mathrm{n}$ & $\%$ & $P$ \\
\hline $0-4$ & 89 & 22.8 & \multirow{5}{*}{0.894} \\
\hline $5-9$ & 114 & 29.2 & \\
\hline $10-14$ & 98 & 25.1 & \\
\hline $15-19$ & 44 & 11.3 & \\
\hline $20+$ & 46 & 11.8 & \\
\hline
\end{tabular}




\begin{tabular}{|c|c|c|c|}
\hline Department of Employment & $\mathrm{n}$ & $\%$ & $\mathrm{P}$ \\
\hline Food-Beverage & 102 & 26.1 & \multirow{9}{*}{0.119} \\
\hline Housekeeping & 87 & 22.3 & \\
\hline Front Office & 35 & 9.0 & \\
\hline Marketing and Sales & 21 & 5.4 & \\
\hline Technical Service & 18 & 4.6 & \\
\hline Accounting & 19 & 4.9 & \\
\hline Security & 30 & 7.7 & \\
\hline Human Resources & 17 & 4.3 & \\
\hline Other & 62 & 15.9 & \\
\hline Years of Experience & $n$ & $\%$ & $\mathrm{P}$ \\
\hline $1-2$ & 145 & 37.1 & \multirow{5}{*}{0.393} \\
\hline $3-4$ & 91 & 23.3 & \\
\hline $5-6$ & 58 & 14.8 & \\
\hline $7-8$ & 48 & 12.3 & \\
\hline $9+$ & 49 & 12.5 & \\
\hline Status of Receiving Tourism Training & $\mathrm{n}$ & $\%$ & $\mathrm{P}$ \\
\hline Yes & 245 & 62.7 & \multirow{2}{*}{0.365} \\
\hline No & 146 & 37.3 & \\
\hline Participation in Tourism as a Tourist & $\mathrm{n}$ & $\%$ & $\mathrm{P}$ \\
\hline Yes & 253 & 64.7 & \multirow{2}{*}{0.637} \\
\hline No & 138 & 35.3 & \\
\hline
\end{tabular}

$p<0,05$

Table 2 shows the distribution of the demographic characteristics for the province of Eskişehir, and displays the test results regarding whether the perceived positive effects of tourists of the tourists differ among the staff groups. According to Table 2, 56.9\% of the total sample is composed of males and $43.1 \%$ are females. The distribution of age groups is as follows: $9.1 \%$ of the staff are 20 and younger, $50.5 \%$ are $21-30,27.5 \%$ are $31-40,11.0 \%$ are $41-50$, and $1.9 \%$ are over 51 years old. By marital status, $43.9 \%$ are married and $56.1 \%$ are single. By the level of educational attainment, $16.1 \%$ are graduates of primary education, $34.2 \%$ of high school, $18.4 \%$ of associate degree, $26.7 \%$ of undergraduate, and $4.6 \%$ of graduate education. Classified by their experience in the tourism sector, $52 \%$ of the employees have $0-4$ years of experience, $32.5 \%$ have $5-9$ years, $8.3 \%$ have $10-14$ years, $3.9 \%$ have $15-19$ years, and $3.3 \%$ have 9 years or longer experience. Categorized by their department of employment, $36.6 \%$ of the employees work in the food and beverage department, $20.3 \%$ in housekeeping services, $22.4 \%$ in front office, $5.8 \%$ in marketing and sales, $5.4 \%$ in technical services, $3.5 \%$ in accounting, $1.0 \%$ in security, $1.4 \%$ in human resources, and $3.5 \%$ are employed in other departments. By their years of work experience in the current establishment, $71.6 \%$ of the employees have 1-2 years of experience, $13.5 \%$ have 3-4 years, $8.3 \%$ have $5-6$ years, $2.9 \%$ have $7-8$ years, and $3.7 \%$ have a work experience of 9 years and over in the hotel. $59.4 \%$ of the people are professionally trained in the tourism sector, and $40.6 \%$ are not. $62.9 \%$ of the employees have participated in tourism as tourists, while $37.1 \%$ have not.

The tests revealed that, regarding the positive effects of tourists, there was a statistically significant difference only between "those professionally trained in tourism and those who are not" and "those having participated in tourism as a tourist and those who have not," at the $95 \%$ con- 
fidence level. Regarding the differences between these two groups, those with no prior training in tourism had a positive average of 2.14 regarding the positive aspects of the tourists, while those with previous tourism training had an average of 1.96. In addition, those having participated in tourism as a tourist themselves had a positive average of 1.96 regarding the positive aspects of the tourists, while those not having done so had an average of 2.16 .

Table 2. Hotel staff opinions by their demographic status (Eskişehir)

\begin{tabular}{|c|c|c|c|}
\hline Gender & $\mathrm{n}$ & $\%$ & $\mathrm{P}$ \\
\hline Male & 275 & 56.9 & \multirow{2}{*}{0.841} \\
\hline Female & 208 & 43.1 & \\
\hline Age Groups & $\mathrm{n}$ & $\%$ & $\mathrm{P}$ \\
\hline 20 and under & 44 & 9.1 & \multirow{5}{*}{0.734} \\
\hline $21-30$ & 244 & 50.5 & \\
\hline $31-40$ & 133 & 27.5 & \\
\hline $41-50$ & 53 & 11.0 & \\
\hline $51+$ & 9 & 1.9 & \\
\hline Marital Status & $\mathrm{n}$ & $\%$ & $\mathrm{P}$ \\
\hline Married & 212 & 43.9 & \multirow{2}{*}{0.882} \\
\hline Single & 271 & 56.1 & \\
\hline Level of Education & $\mathrm{n}$ & $\%$ & $\mathrm{P}$ \\
\hline Primary & 78 & 16.1 & \multirow{5}{*}{0.917} \\
\hline High School & 165 & 34.2 & \\
\hline Associate & 89 & 18.4 & \\
\hline Undergraduate & 129 & 26.7 & \\
\hline Graduate & 22 & 4.6 & \\
\hline Experience in the Sector & $\mathrm{n}$ & $\%$ & $P$ \\
\hline $0-4$ & 251 & 52.0 & \multirow{5}{*}{0.384} \\
\hline $5-9$ & 157 & 32.5 & \\
\hline $10-14$ & 40 & 8.3 & \\
\hline $15-19$ & 19 & 3.9 & \\
\hline $20+$ & 16 & 3.3 & \\
\hline Department of Employment & $\mathrm{n}$ & $\%$ & $\mathrm{P}$ \\
\hline Food-Beverage & 177 & 36.6 & \multirow{9}{*}{0.907} \\
\hline Housekeeping & 98 & 20.3 & \\
\hline Front Office & 108 & 22.4 & \\
\hline Marketing and Sales & 28 & 5.8 & \\
\hline Technical Service & 26 & 5.4 & \\
\hline Accounting & 17 & 3.5 & \\
\hline Security & 5 & 1.0 & \\
\hline Human Resources & 7 & 1.4 & \\
\hline Other & 17 & 3.5 & \\
\hline
\end{tabular}




\begin{tabular}{|c|c|c|c|}
\hline Years of Experience & $\mathrm{n}$ & $\%$ & $P$ \\
\hline $1-2$ & 346 & 71.6 & \multirow{5}{*}{0.335} \\
\hline $3-4$ & 65 & 13.5 & \\
\hline $5-6$ & 40 & 8.3 & \\
\hline $7-8$ & 14 & 2.9 & \\
\hline $9+$ & 18 & 3.7 & \\
\hline Status of Receiving Tourism Training & $n$ & $\%(\bar{x})$ & $p$ \\
\hline Yes & 287 & $59.4(1.96)$ & \multirow{2}{*}{$0.017^{*}$} \\
\hline No & 196 & $40.6(2.14)$ & \\
\hline Participation in Tourism as a Tourist & $\mathrm{n}$ & $\%$ & $P$ \\
\hline Yes & 304 & $62.9(1.96)$ & \multirow{2}{*}{$0.007^{*}$} \\
\hline No & 179 & $37.1(2.16)$ & \\
\hline
\end{tabular}

${ }^{*} p<0,05$

\section{Discussion and Conclusion}

The main objective of this research was to determine whether, by their demographic status, hotel staff' opinions about the positive attributes of tourists differ. The survey was conducted in Antalya, a popular destination for coastal tourism; and Eskişehir, which is popular for cultural tourism. The survey included questions about the demographic information of the employees and their perceptions of some positive tourist effects. Based on the hotel staff's demographic data, no statistically significant difference was identified in their perceptions regarding the positive qualities of tourists. According to the statistics posted by the Provincial Directorate of Culture and Tourism, between the years of 2012 and 2015, an average of 10 million people visited Antalya (http://www.antalyakulturturizm.gov.tr). Tourism is the most important source of income for the economy of Antalya. Antalya is one of the busiest tourism destinations in Turkey, and cities of investment activities, and so it has a remarkable degree of experience in tourism. From public institutions to local governments, from tourism entrepreneurs to non-governmental organizations, from hotel managers to transfer staff, all sorts of institutions and individuals in Antalya are involved in the tourism sector, which positively affects individuals' viewpoints about "tourism and tourists". Furthermore, it can be safely assumed that the hotel staff in Antalya have enough knowledge and experience to know who the tourists are and why they are traveling. Thus, it can be considered natural that the differences in the perceptions of the positive effects of tourists do not vary by the hotel employee demographics.

The results of the data obtained from the hotel staff in Eskişehir revealed that, there was a statistically significant difference between "those trained in tourism and those not trained in tourism" and "those having participated in tourism as a tourist and those who have not," regarding the positive effects of the tourists. Eskişehir is a popular destination for cultural tourism both domestically and internationally. In addition, the two universities in Eskişehir also contribute to the artistic and cultural enrichment of the city. Regarding the positive effects of tourists, the opinions of hotel staff without tourism training are more positive than of those trained in tourism. Those with formal education background in the tourism field are more optimistic about the issue perhaps because they are more knowledgeable about the tour- 
ist profile. The views of those who are not formally educated in tourism seem to be colored by a worry about making mistakes and fear of losing their job. The same is true for the opinions of those who did not participate in tourism as a tourist. Those without any experience of tourism as a tourist seem to be more positive about the effects of the tourist, which leads to the following question: "Does the hotel staff's participation in tourism as tourists influence their views on the positive effects of the tourist?" Such questions pave the way for new research inquiries. Knowing the opinions of the hotel staff about the positive effects of tourists and staff's attitudes about them will primarily contribute to the establishment, the tourists, and the stakeholders. The hotel employee who can satisfactorily answer the questions of who the tourist is and why s/he is traveling will always benefit the tourism sector. For this reason, hotel operators need to be judicious and careful about their choice of employees and their job satisfaction. Replicating this study with regular intervals at different tourism destinations will ensure obtaining more profound insights, drawing firmer conclusions, and achieving results with higher validity and reliability. The scope of this study is limited to hotel operations. Conducting further research in tourism establishments in other locations will enable stakeholders involved in the tourism sector to make a more accurate, in-depth and productive assessment of the current study from a broader perspective as well.

\section{References}

Ahmed, S. A. 1987. Perceptions of Socio-Economic and Cultural Impact of Tourism in Sri-Lanca: A Research Study. Marga Quarterly Journal 8 (4), 34-63.

Ateşoğlu, İ., Türker, A. 2013. Türkiye'yi Ziyaret Eden Turistlerin Algıladıkları Ülke İmajı ve Olumsuz Algılara İlişkin Çözüm Önerileri”, Yenifikir Uluslararası Hakemli Akademik Fikir Araştırma Dergisi, Cilt 1, sayı 10, 112-135.

Boğan, E., Sarıșık, M. 2016. Yerel halkın Turizm Faaliyetine Yönelik Görüş ve Algılamalarının Belirlenmesi Üzerine Alanya'da Bir Araştırma, Kastamonu Üniversitesi İktisadi ve İdari Bilimler Fakültesi Dergisi, Nisan 2016, Say1:12, 325-342.

Burkart, A. J., Medlik, S. 1986. Tourism, Past, Present and Future, He-inemann: London.

Çalışkan, O., Ünüsan, Ç. 2011. Otel Çalışanlarının Kurumsal Sosyal Sorumluluk Algısının İş Tatmini ve İşte Kalma Niyetine Etkisi, Anatolia: Turizm Araştırmaları Dergisi, Cilt 22, Sayı 2, 54-166.

Doğan, H. Z. 2004. Turizmin Sosyo-Kültürel Değerleri, Detay Yayıncılık, Ankara

Egbali, N., Nosrat, A.B., Pour, S.K.S.A. 2011. Effects of Positive and Negative Rural Tourism (Case Study: Rural Semnan Province). Journal of Geography and Regional Planning 4(2), 63-76.

Eralp, Z. 1974. Turizmin Toplumsal Değişime Sosyo-Ekonomik Etkisi, Ankara Üniversitesi Siyasal Bilgiler Fakültesi Yayınları: 374, Ankara.

Kattara, H. S., Weheba, D., Ahmed, O. 2015. The impact of Employees' Behavior on Customers' Service Quality Perceptions and Overall Satisfaction. African Journal of Hospitality, Tourism and Leisure 4 (2) Special Edition, 1-15.

Keung, S. W. C. 200o. Tourists' Perceptions of Hotel Frontline Employees' Questionable Job-Related Behaviour. Tourism Management 21, 121-134.

Kongprasert, N., Virutamasen, P. 2015. Tourist Perceptions of Cultural Identity: The Case of Thai Experience. Procedia - Social and Behavioral Sciences 195, 167-174. 
Matzler, K., Strobl, A., Stokburger-Sauer, N., Bobovnicky, A. 2016. Brand Personality And Culture: The Role of Cultural Differences on the Impact of Brand Personality Perceptions on Tourists' Visit Intentions. Tourism Management 52, 507-520.

Özdamar, K. 2001. Paket Programlar ve İstatistiksel Veri Analizi (Çok Değişkenli Analizler). (4. Baskı), Eskișehir: Kaan Yayınları.

Özel, Ç. H. 2010. Güdülere Dayalı Yerli Turist Tipolojisinin Belirlenmesi: İç Turizm Pazarına Yönelik Bir Uygulama, Anadolu Üniversitesi Sosyal Bilimler Enstitüsü, Turizm ve Otel İşletmeciliği Anabilim Dalı, Doktora Tezi, Eskişehir.

Rahman, M. S. 2012. Exploring Tourists' Perception: The Case of Bangladesh. Tourismos: An International Multidisciplinary Journal of Tourism 7(1), 81-98.

Roney, A. S. 2011. Turizm (Bir Sistemin Analizi), Detay Yayıncılık, Ankara

Tan, S. K., Luh, D. B., Kung, S. F. 2014. A Taxonomy of Creative Tourists in Creative Tourism. Tourism Management 42, 248-259.

Toksay, T. 1989. Turizm, Turizm Olayına Genel Yaklaşım, Der Yayınları, İstanbul

Toprak, L. 2015. Mardin'de Halkın Turizm Algısı. Elektronik Sosyal Bilimler Dergisi 14 (54), 201-218.

Tsartas, P. 1992. Socioeconomic Impacts of Tourism on Two Greek Isles. Annals of Tourism Research 19(3), 516-533.

Türker, G. Ö., Türker, A. 2014. Yerel Halkın Turizm Etkilerini Algılama Düzeyi Turizm Desteğini Nasıl Etkiler: Dalyan Destinasyonu Örneği. Electronic Journal of Vocational Colleges $1(4), 81-98$.

Varol, İ. 2015. Turist Algılarının Davranışsal Niyetler Üzerindeki Etkisi: Edremit Körfezi Örneği, T.C. Balıkesir Üniversitesi Sosyal Bilimler Enstitüsü Turizm İşletmeciliği Anabilim Dalı Yüksek Lisans Tezi, Balıkesir.

Yılmazer, A., Bahadır, İ. 2011. Otel İşletmelerinde Önbüro Çalışanlarının Etik Algılamalarına Yönelik Bir Araştırma, Ç.Ü. Sosyal Bilimler Enstitüsü Dergisi, Cilt 2o, Sayı 3, 21-40.

\section{$\||\|\mid\|$}

Internet 1: http://www.resmigazete.gov.tr/main.aspx?home=http://www.resmigazete.gov.tr/ arsiv/7217.pdf\&main=http://www.resmigazete.gov.tr/arsiv/7217.pdf (24.10.2017)

Internet 2: http://www.antalyakulturturizm.gov.tr/TR,175865/yabanci-ziyaretci-sayilari-ve-milliyet-dagilimi-2012-20-html (o1.11.2017)

Internet 3: Aybay, R. 1979. Bir İnsan Hakkı Olarak Uluslararası Seyahat Özgürlüğü, http:// www.todaie.edu.tr/resimler/ekler/2ef9gfbbagac8f1_ek.pdf?dergi=Insan\%2oHaklari\%2oYilligi (24.10.2017)

Internet 4: World Tourism Organization, 2016. http://cf.cdn.unwto.org/sites/all/files/pdf/ annual_report_2016_web_o.pdf (24.10.2017) 